\title{
Why have Pneumocystis carinii trophozoites been ignored?
}

\author{
J M W Chatterton, A W L Joss, M M Davidson, D O Ho-Yen
}

\begin{abstract}
Introduction
The recent classification of Pneumocystis carinii as a fungus was the result of detailed investigations. ${ }^{\prime}$ Equally fundamental observations remain to be made on this organism's life cycle and pathogenicity. Although trophozoites and cysts of $P$ carinii have been described in infected lung, ${ }^{2}$ their role and relative importance have not been clearly established. Despite this uncertainty investigators have mainly concentrated on cysts. The possibility that trophozoites are clinically more important and antigenically different deserves further examination. In this paper we consider how and to what extent they have been overlooked and the implications for the development of diagnostic tests for $\boldsymbol{P}$ carinii pneumonia (PCP).
\end{abstract}

\section{Reagents}

The specificity and sensitivity of laboratory tests greatly depend on the quality of the reagents. $P$ carinii cysts are easily identified because their size and shape are consistent and they stain in a predictable way with widely used stains such as Grocott's methenamine silver, toluidine blue $O$, or cresyl violet. In contrast, trophozoites are pleomorphic, variable in size, and do not stain with these stains. They stain with Giemsa or Diff-Quick but are difficult to identify and are best demonstrated by electron microscopy (figure).

The precise relation between cysts and trophozoites is unknown. Trophozoites may

\section{Microbiology Raigmore Hospital Inverness IV2 3U] \\ $\mathrm{J} M$ W Chatterton A W L Joss M Davidso Correspondence to: Dr Ho-Yen. Accepted for publication 12 October 1989}

develop into cysts ${ }^{2}$ or may replicate independently. ${ }^{3}$ The latter could explain why they are often more numerous. Indeed, it has been estimated that cysts may represent less than $1 \%$ of $P$ carinii parasites in an alveolar lavage. ${ }^{4}$ This suggests that trophozoites are more important than cysts in the growth of the parasite, and in tissue culture studies trophozoites provide the most sensitive indicator of growth. ${ }^{5}$ Furthermore, the number of cysts does not correlate with the severity of $\mathrm{PCP}^{6}$ and drugs effective in PCP seem to have greater effect on trophozoites than cysts. ${ }^{27}$

Test reagents for $P$ carinii are prepared from parasites purified from tissue culture ${ }^{8}$ or more commonly from infected lung. Necropsy samples of human lung are scarce so infected rat lung produced by immunosuppression is widely used. ${ }^{9}$ Because of their resistant nature and easy identification most purification procedures favour cyst separation ${ }^{10-12}$ with little attention devoted to the fate of trophozoites. ${ }^{11}$ Cysts can survive combinations of mechanical and enzyme treatments, differential centrifugation, and gradient separation techniques, but enzymes affect their morphology and immunological activity. Thus pronase and trypsin treatments can produce cysts which react differently in indirect immunofluorescence (IFA) tests and noticeably reduce numbers of trophozoites, ${ }^{9}$ but collagenase does not seem to affect either cysts or trophozoites. ${ }^{11}$

\section{Serological studies}

Serological tests have used cyst rich fractions. Trophozoites have been shown to persist in such fractions, ${ }^{11}$ but only cyst numbers are usually evaluated because they are easier to show and quantity. Differences in purity and quality of cysts or trophozoites might therefore explain the differences in reactivities which have been reported. It is assumed that cysts and trophozoites are antigenically identical but the evidence for this is not convincing. Although trophozoites have been found to react with antisera against cysts, ${ }^{11}$ this could be explained by trophozoites contaminating cyst fractions used to prepare the antisera.

Variability in antigen composition could also explain the results obtained when comparing parasites from different species. Rat and human $P$ carinii have been reported to be antigenically similar, ${ }^{13}$ antigenically distinct, ${ }^{14}$ or to have specific and common antigens. ${ }^{15}$ Workers have been cavalier in their use of rat
Rat lung infected with $P$ carinii; single thick walled cyst $(C)$ with developing intracystic bodies and numerous trophozoites (T) Scale bar $=2 \mu \mathrm{m}$. 
Table 1 Results of $P$ carinii antigenaemia using sera from immunised rabbits

\begin{tabular}{|c|c|c|c|c|c|}
\hline \multicolumn{2}{|c|}{ Reference } & \multirow{2}{*}{$\frac{\text { Method }}{\text { CIE }}$} & \multirow{3}{*}{$\begin{array}{l}\text { Immunogen } \\
\text { Human and rat cysts, } \\
\text { in vitro culture, trypsinised, } \\
\text { gradient separation, sonicated } \\
\text { As (1) }\end{array}$} & \multirow{4}{*}{$\begin{array}{l}\text { Groups examined } \\
123 \mathrm{PCP} / \text { cancer } \\
100 \text { cancer } \\
120 \text { normal } \\
28 \mathrm{BMT} / \mathrm{PCP} \\
80 \text { other pneumonia } \\
25 \mathrm{BMT} \\
50 \mathrm{BMT} \text { donors } \\
20 \mathrm{PCP} \\
1 \text { control }\end{array}$} & \multirow{3}{*}{$\begin{array}{c}\text { Results and conclusions } \\
\text { Positive in } 67 \% \text { PCP, } \\
15 \% \text { cancer and } \\
0 \% \text { normal controls } \\
\text { Positive in } 79 \% \text { PCP, } \\
71 \% \text { other pneumonia, } \\
44 \% \text { BMT, } 2 \% \text { donors } \\
\text { not diagnostic }\end{array}$} \\
\hline 1 & Pifer $e t a l^{21} 1978$ & & & & \\
\hline 2 & $\begin{array}{l}\text { Meyers et al } \\
1979\end{array}$ & $\mathrm{CIE}$ & & & \\
\hline 3 & $\begin{array}{l}\text { Maddison et al }{ }^{17} \\
1982\end{array}$ & $\begin{array}{l}\text { a) ELISA } \\
\text { b) CIE }\end{array}$ & $\begin{array}{l}\text { Rat cysts, collagenase } \\
\text { treated, gradient separation, } \\
\text { HCl soluble }\end{array}$ & & \\
\hline 4 & $\begin{array}{l}\text { Maddison et al } \\
1982\end{array}$ & CIE & As (3) & $\begin{array}{l}102 \text { PCP } \\
153 \text { contacts } \\
99 \text { healthy subjects } \\
24 \text { AIDS/PCP }\end{array}$ & $\begin{array}{l}\text { Positive in } 13.7 \% \text { PCP, } \\
3 \% \text { contacts } 1 \% \text { healthy, } \\
51 \% \text { AIDS } / \text { PCP, } \\
\text { insensitive }\end{array}$ \\
\hline 5 & $\begin{array}{l}\text { Maddison et al }{ }^{19} \\
1984\end{array}$ & CIE & As (3) & $\begin{array}{l}32 \text { AIDS/PCP } \\
135 \text { controls }\end{array}$ & $\begin{array}{l}\text { Positive in } 41 \% \text { PCP; } \\
20 \% \text { healthy controls; } \\
\text { unreliable indicator }\end{array}$ \\
\hline 6 & $\begin{array}{l}\text { Tanabe et al } \\
1985\end{array}$ & CIE & $\begin{array}{l}\text { Rat cysts, collagenase } \\
\text { treated, filtration, sonicated }\end{array}$ & 13 PCP & $\begin{array}{l}23 \% \text { positive } \mathrm{PCP}, \\
0 \% \text { controls }\end{array}$ \\
\hline 7 & $\begin{array}{l}\text { Jarowenko et } a l^{20} \\
1986\end{array}$ & $\begin{array}{l}\text { CIE } \\
\text { LPA }\end{array}$ & $\begin{array}{l}\text { Rat cysts in } \\
\text { vitro culture }\end{array}$ & $\begin{array}{rl}7 & \mathrm{RT} / \mathrm{PCP} \\
78 & \mathrm{RT} / \text { asymptomatic } \\
100 & \text { healthy subjects }\end{array}$ & $\begin{array}{l}\text { CIE positive in } 28 \% \\
\text { PCP, } 1 \% \text { asymptomatics and } \\
0 \% \text { healthy subjects, LPA } \\
\text { positive in } 100 \% \text { PCP, } \\
62 \% \text { of asymptomatics and } \\
5 \% \text { normal controls }\end{array}$ \\
\hline 8 & $\begin{array}{l}\text { Tanabe and } \\
\text { Furuta }{ }^{24} 1987\end{array}$ & $\begin{array}{l}\text { ELISA } \\
\text { CIE }\end{array}$ & $\begin{array}{l}\text { Cysts from athymic nude } \\
\text { rats extracted as (6) }\end{array}$ & 10 PCP & $\begin{array}{l}\text { ELISA } 80 \% \text { positive; } \\
\text { CIE } 20 \% \text { positive }\end{array}$ \\
\hline 9 & Pifer et al ${ }^{25} 1988$ & CIE & Rat cysts $(1)$ & $\begin{array}{l}12 \text { AIDS/PCP } \\
106 \text { AIDS/clinical PCP }\end{array}$ & $\begin{array}{l}\text { Positive in } 75 \% \text { confirmed } \\
\text { PCP, } 30 \% \text { others }\end{array}$ \\
\hline
\end{tabular}

BMT, Bone marrow transplant; RT, renal transplant; LPA, latex particle agglutination; CIE, counterimmunoelectrophoresis.

and human parasites, enzyme treated or untreated and purified on gradients of different compositions. These antigens and antisera may not be interchangeable.

Reports on the usefulness of IFA for antibody detection in human serum have varied widely. ${ }^{16}$ There is little agreement on the best source and method of antigen preparation for IFA, and apparently similar antigens give different results. Soluble antigens derived from disrupted cysts have been used in enzyme linked immunosorbent assays (ELISA) for antibody detection. ${ }^{17-20}$ The good correlation between IFA and ELISA suggests that similar wall antigens are involved. Although the ELISA is more sensitive than IFA, it is no more specific to PCP. ${ }^{1820} \mathrm{It}$ is perhaps relevant that ELISA antigens are assessed on concentration of cysts, yet numbers do not correlate with the protein concentrations of the final preparations. ${ }^{17}$ This may be due to contaminating tissue proteins, but the contribution of trophozoites could be important. The activity of IFA and ELISA antigens prepared from trophozoite rich fractions remains to be studied.

\section{Current infection}

Identification of $P$ carinii specific antigen in serum allows current infection to be diagnosed. Initially, promising results were obtained using sera from immunised rabbits (table 1), but these tests have proved insensitive. Reliable differentiation of clinical PCP from subclinical infection is not possible, ${ }^{17-25}$ but antigenaemia has been found in patients with PCP before the appearance of antibody and the onset of acute pneumonia. ${ }^{24}$ Although trophozoites have been shown to be more numerous than cysts, particularly in early PCP, anti-trophozoite specific antisera have not been evaluated in antigen detection systems.

Monoclonal antibody technology has enabled production of $P$ carinii specific antibodies despite crude starting antigen. ${ }^{26-30}$ These antibodies have been used in IFA tests for simple, rapid, and highly specific demonstration of $P$ carinii in clinical specimens. ${ }^{28-32}$ The monoclonal antibodies so far available have been selected to react with cyst wall antigens. They seem to be capable of detecting at least $95 \%$ of human isolates from patients with AIDS and non-AIDS patients. ${ }^{28}$ These workers suggest that only visualisation of characteristic cysts should be considered diagnostic. In one study, however, ${ }^{32}$ free trophozoites and a few cysts were found in one patient and only thin walled cysts in another of $19 P$ carinii positive bronchoalveolar lavage samples. Thus if the diagnosis of current infection depends on the presence of cysts, cases could be missed.

Antigenaemia was detected in only $11 \%$ of heavily infected rats using anti-rat $P$ carinii monoclonal antibodies in a sandwich ELISA. ${ }^{33}$ Antigen was detected in the supernate and pellet of lavage fluid taken during acute infection, but there was no correlation between absorbance values and the numbers of cysts present. Trophozoite populations were not evaluated and may be responsible for these discrepancies. It would be interesting to know if monoclonal antibodies that recognise trophozoite specific antigens would have been more successful.

\section{New techniques}

Immunoblotting (Western blot) has only recently been applied to $P$ carinii. As with the development of monoclonal antibodies trophozoites must be present in the crude extracts applied to the polyacrylamide gels. Antigens chosen for immunoblotting based on the highest protein concentrations did not correlate with highest cyst numbers. ${ }^{34}$ Yet little effort has been made specifically to investigate trophozoite antigen or even determine relative cyst and trophozoite numbers. Rat and human 
Table 2 Results of Western blot analysis of $P$ carinii antigens using normal and infection derived human and rat sera (Major bands underlined)

\begin{tabular}{|c|c|c|c|c|c|c|c|}
\hline \multirow{2}{*}{$\begin{array}{l}\text { Antigen } \\
\text { source }\end{array}$} & \multirow{2}{*}{$\begin{array}{l}\text { Bands } \\
\text { detected } \\
(K d)\end{array}$} & \multicolumn{2}{|c|}{ Human sera } & \multicolumn{3}{|c|}{ Rat sera } & \multirow[b]{2}{*}{ Reference No } \\
\hline & & $N$ & $P$ & $N$ & $E$ & $R$ & \\
\hline Rats & $\begin{array}{l}30-32 \\
35-40 \\
\frac{45}{50-60} \\
\frac{60-92}{110-116} \\
\frac{1125}{170}\end{array}$ & $\begin{array}{l}+ \\
+ \\
+ \\
+ \\
+ \\
+ \\
+ \\
+\end{array}$ & $\begin{array}{l}+ \\
+ \\
+ \\
+ \\
+ \\
+ \\
+ \\
+\end{array}$ & $\begin{array}{l}+ \\
+ \\
+ \\
+ \\
+ \\
+\end{array}$ & $\begin{array}{l}+ \\
+ \\
+ \\
+ \\
+\end{array}$ & $\begin{array}{l}+ \\
+ \\
+ \\
+ \\
+ \\
+ \\
+ \\
+\end{array}$ & $\begin{array}{l}36 \\
35,36,37 \\
34,37 \\
33,34,36,37 \\
34,37 \\
33,34,35,36,37 \\
36 \\
33,36\end{array}$ \\
\hline Man & $\begin{array}{l}40 \\
66\end{array}$ & + & + & & $\cdot+$ & + & $\begin{array}{l}34 \\
34\end{array}$ \\
\hline
\end{tabular}

$\mathrm{N}=$ normal healthy controls/rats with anti-P carinii antibody

$\mathrm{P}=$ Patients with PCP

$\mathrm{E}=$ Healthy rats exposed to $P$ carinii

$\mathrm{R}=\mathrm{PCP}$ induced in rats
$\mathrm{R}$ that the more numerous trophozoites so often ignored in immunological studies may hold the key to effective diagnosis of PCP.

We are grateful to Miss Vivian MacFarquhar for secretarial assistance.

1 Edman JC, Kovacs JA, Masur H, Santi DV, Elwood MJ, Sogin ML. Ribosomal RNA sequence shows Pneumocystis carinii to be a member of the fungi. Nature 1988;334:519-22.

2 Campbell WG. Ultrastructure of Pneumocystis in human lung. Archives of Pathology 1972;93:312-24.

3 Vossen MEMH, Beckers PJA, Meuwissen JHETh, Stadhouders AM. Developmental biology of Pneumocystis carnii, an alternative view on the life cycle of the parasite. Zeitschrift für Parasitenkende 1978;55:101-18.

4 Masur H, Jones TC. The interaction in vitro of Pneumocystis carinii with macrophages and L cells. $J$ Exp Med 1978;147:157-70.

5 Cushion MT, Walzer PD. Growth and serial passage of Pneumocystis carinii in the A549 cell line. Infect Immun 1984;44:245-51.

antigen preparations have been probed using serum from immunised rabbits, ${ }^{33}{ }^{34}$ monoclonal antibodies, ${ }^{303335}$ and infection derived sera from rats or humans ${ }^{33-37}$ (table 2).

With rat antigen, major bands at $45,50-60$, and 110-116 kilodaltons are most consistently shown, while detection of the other polypeptides is variable. Only the 45 kilodalton band may be specific for $P$ carinii as bands at 55-60 and 110 have been found in normal rat lung antigen, ${ }^{36}$ suggesting they are due to rat proteins or cysts in normal lung. In human $P$ carinii an 82 kilodalton polypeptide seems to be important as 17 of 21 anti-human $P$ carinii monoclonal antibodies reacted only with this single polypeptide.$^{30}$ Another study identified a 40 and to a lesser extent a 66 kilodalton polypeptide as the principal immunoreactive bands in human $P$ carinii. ${ }^{34}$ These bands were detected in six of seven $P$ carinii isolates from patients with AIDS but in only one isolate of eight patients without AIDS. Cyst counts in these preparations were similar, but trophozoites were not counted. Higher numbers of trophozoites might have contributed to the antigenicity of the AIDS specimens. A further contributing factor may have been the storage of specimens: three of eight non-AIDS specimens had been stored at $-70^{\circ} \mathrm{C}$ for 11 years and thawed and stored at $-20^{\circ} \mathrm{C}$ on a number of occasions. Thus trophozoites may have been preferentially destroyed.

Analysis of $P$ carinii by immunoblotting has not helped clinical decisions as studies have reported little difference in results obtained with serum from healthy subjects and patients with PCP, ${ }^{34}{ }^{36}$ or between recovered and rats with PCP. ${ }^{36} 37$

\section{Conclusion}

Reagents prepared from $P$ carinii parasites have been of limited use in the serological diagnosis of PCP. For technical reasons cyst rich antigens have been selected for investigation and trophozoite antigens have not been properly evaluated. Cysts and trophozoites may not be antigenically identical and contamination of cyst antigens by trophozoites may explain some of the anomalies of serological testing. Future developments require a better understanding of $P$ carinii antigens and more effort must be devoted to specific analysis of trophozoites. We believe
6 Kovacs JA, Hiemenz JW, Macher AM, et al. Pneumocystis carinii pneumonia: a comparison between patients with the acquired immunodeficiency syndrome and patients the acquired immunodeficiency syndrome and patients
with other immunodeficiencies. Ann Intern Med 1984; 100:663-71.

7 Hasleton PS, Curry A, Rankin EM. Pneumocystis carini study. J Clin Pathol 1981;34:1138-46.

8 Pifer LL, Hughes WT, Murphy MJ. Propagation of Pneumocystis carinii in vitro. Pediatr Res 1977;11:305-16.

9 Walzer PD. Experimental models of Pneumocystis carini infections. In: Young LS, ed. Pneumocystis carinil pneumonia. Lung biology in health and disease. Vol 22 . New York: Marcel Dekker, 1984:7-76.

10 Meuwissen JHETh, Leeuwenberg ADEM, Heeren J, Stumpel A. New method for study of infections with Stumpel A. New method for study of infections

11 Walzer PD, Rutledge ME, Yoneda K, Stahr BJ. Pneumocystis carinii: new separation method from lung tissue. Exp Parasitol 1979;47:356-68.

12 Yoshida Y, Ikai T. Pneumocystis carinii pneumonia Epidemiology in Japan, and cyst concentration method Zbl ZentralbL Bakteriol Orig A 1979;244:405-10.

13 Ikai T. Pneumocystis carinii: production of antibody either specific to trophozoite or to cyst wall. Jap J Parasitol 1980;29:115-26.

14 Kim HK, Hughes WT, Feldman S. Studies of morphology and immunofluorescence of Pneumocystis carinii. Proc Soc Exp Biol Med 1972;141:304-9.

15 Walzer PD, Rutledge ME. Comparison of rat, mouse, and human Pneumocystis carinii by immunofluorescence. $J$ Infect Dis 1980;142:449.

16 Chatterton JMW, Joss AWL, Williams H, Ho-Yen DO Pneumocystis carinii antibody testing. J Clin Pathol 1989;42:865-8.

17 Maddison SE, Hayes GV, Ivey MH, Tsang VCW Slemenda SB, Norman LG. Fractionation of Pneumocystis carinii antigens used in an enzyme linked immunosorbent assay for antibodies and in the production of antiserum for detecting Pneumocystis carinii antigenemia. J Clin Microbiol 1982;15:1029-35.

18 Maddison SE, Hayes GV, Slemenda SB, Norman LG, Ivey MH. Detection of specific antibody by enzyme linked Pneumocystis carinii. J Clin Microbiol 1982;15:1036-43.

19 Maddison SE, Walls KW, Haverkos HW, Juranek DD Evaluation of serologic tests for Pneumocystis carinii antibody and antigenemia in patients with acquired 1984;2:69-73.

20 Jarowenko M, Pifer L, Kerman R, Kahan BD. Serologic methods for the early diagnosis of Pneumocystis carinii infection in renal allograft recipients. Transplantation 1986;41:436-42.

21 Pifer LL, Hughes WT, Stagno S, Woods D. Pneumocystis carinii infection: evidence for high prevalence in normal and immunosuppressed children. Pediatrics 1978;61 $35-4$

22 Meyers JD, Pifer LL, Sale GE, Thomas ED. The value of Pneumocystis carinii antibody and antigen detection for diagnosis of Pneumocystis carinii pneumonia after marrow transplantation. Am Rev Respir Dis 1979;120: 1283-7.

23 Tanabe K, Furuta T, Ueda K, Tanaka H, Shimada K. Serological observations of Pneumocystis carinii infection in humans. J Clin Microbiol 1985;22:1058-60.

24 Tanabe K, Furuta $T$. Detection of circulating antigens of Pneumocystis carinii in human sera by a sandwich Pneumocystis carinii in human sera by a sandwich
enzyme-immunoassay. ZentrabL Bakteriol Mikrobiol Hyg
A 1987;264:373-8.

25 Pifer LW, Wolf BL, Weems JJ Jr, Woods DR, Edwards CC Joyner RE. Pneumocystis carinii antigenemia in acquired immunodeficiency syndrome. J Clin Microbiol 1988;26: 1357-61.

26 Lee C-H, Bolinger CD, Bartlett MS, Kohler-RB, Wilde CE III, Smith JW. Production of monoclonal antibody spleen and mouse myeloma cells. J Clin Microbiol 1986; pneumonia: a light microscopical and ultrastructura immunosorbent assay and antigenemia by counterimmunoelectrophoresis in humans infected with immunodeficiency syndrome. Diagn Microbiol Infect Dis against Pneumocystis carinii by using a hybrid of rat 
27 Gigliotti F, Stokes DC, Cheatham AB, Davis DS, Hughes WT. Development of murine monoclonal antibodies to Pneumocystis carinii. J Infect Dis 1986;154:315-22.

28 Gill VJ, Evans G, Stock F, Parrillo JE, Masur H, Kovacs JA Detection of Pneumocystis carinii by fluorescentantibody stain using a combination of three monoclonal antibodies. J Clin Microbiol 1987;25:1837-40.

29 Kovacs JA, Gill V, Swan JC, et al. Prospective evaluation of a monoclonal antibody in diagnosis of Pneumocystis carinii pneumonia. Lancet 1986;ii:1-3.

30 Linder E, Lundin L, Vorma H. Detection of Pneumocystis carinii in lung-derived samples using monoclonal antibodies to an $82 \mathrm{kD}$ parasite component. J Immunol Methods 1987;98:57-62.

31 Linder E, Elvin K, Björkman A, et al. Monoclonal antibody to detect Pneumocystis carinii. Lancet 1986;ii:634.

32 Elvin KM, Björkman A, Linder E, Heurlin N, Hjerpe A Pneumocystis carinii pneumonia: detection of parasites in sputum and bronchoalveolar lavage fluid by monoclonal sputum and bronchoalveolar lavage fiuid
antibodies. $\operatorname{Br} M e d ~ J 1988 ; 297: 381-4$.
33 McNabb SJN, Graves DC, Kosanke SD, Moyer MJ, Ivey MH. Pneumocystis carinii antigen detection in rat serum and lung lavage. $J$ Clin Microbiol 1988;26:1763-71.

34 Walzer PD, Linke MJ. A comparison of the antigenic characteristics of rat and human Pneumocystis carinii by immunoblotting. J Immunol 1987;138:2257-65.

35 Graves DC, McNabb SJN, Ivey MH, Worley MA. Development and characterisation of monoclonal antibodies to Pneumocystis carinii. Infect Immun 1986;51: bodies $125-33$.

36 Graves DC, McNabb SJN, Worley MA, Downs TD, Ivey MH. Analyses of rat Pneumocystis carinii antigens recognised by human and rat antibodies by using western immunoblotting. Infect Immun 1986;54:96-103.

37 Walzer PD, Stanforth D, Linke MJ, Cushion MT. Pneumocystis carinii: immunoblotting and immunofluorescent analyses of serum antibodies during experimental rat infection and recovery. Exp Parasitol 1987;63: 319-28. 